6 This chapter illustrates how citizenship is being experienced and/or enacted by people across

7 Europe who self-identify with the name Roma or who are routinely identified by others by

8 that name. I use the term Roma not to refer to a fixed cultural identity but rather to a social

9 position marked by a broad variety of socio-economic characteristics; for that reason the name

10 subsumes a host of other designations. Communities who represent themselves traditionally as

11 Sinti, Khale, Ashkali, Romungre, Gypsies, Travellers, Gens de Voyage, and so forth may not

12 always see themselves as part of the same overarching cultural group (Liégeois and Gheorghe,

13 1995), but I regard their perspectives here too as 'Romani', because they are often conceived

14 as such by activists as well as outsiders. The activists in question are usually organized in politi-

$15 \mathrm{cal}$ and non-political Romani organizations and Roma-supporting associations and claim to

16 speak for the broader group, primarily but not exclusively in order to defend the interests of the

17 thus conceived group in the face of threats of marginalization and discrimination. They form a

18 'movement', not in the sense of a clearly defined and bounded collection of officially recognized

19 organizations, but as a diverse totality of actors and activities - formal and informal - interested

20 in defending and cultivating a shared Romani identity (Vermeersch, 2006). They interact with

21 outsiders involved in defining the Roma - these outsiders can be (academic) researchers and

22 experts (on their role see, e.g. Lucassen, Willems and Cottaar (1998), van Baar (2012b) or

23 Vermeersch (2005)), or politicians, policymakers, and civil servants responsible for promot-

24 ing, designing, and implementing local, national, or European 'Roma policies' (Kovats, 2001;

25 Simhandl, 2006; Vermeersch, 2013; van Baar, 2012b). Moreover, the term Roma has now also

26 found currency among a larger public, who employ the term as a supposedly more neutral name

27 to refer to populations formerly called 'Gypsies' (Petrova, 2003). That latter term is often associ-

28 ated by the larger public with such characteristics as a common exotic culture, non-European

29 origins, and lack of a kin state. The complex group formation processes that ensue from all

30 these labelling and framing efforts are further compounded by long-standing popular visions of

31 'Gypsies' as an immutable and archaic group of eternal outcasts. These images feed into severe

32 present-day forms of hate speech and racism, and fuel extremism (Woodcock, 2007; Stewart,

33 2012). In other words, even those who do not see themselves as part of any collective identity

34 group associated with the term 'Gypsies' are nevertheless often hated as 'Gypsies'. 


\section{Peter Vermeersch}

From the outset it is important to emphasize that while membership in a Romani community is often experienced as a matter of cultural givenness, it is at the same time a form of identification that is variable across time and context. I consider Romani identity rather than a measurable enduring fact, like any other form of ethnic identity, as a matter of situational contingency. I follow here a host of authors who have developed a social interaction approach to ethnicity, which focuses not on culture but on practices of categorizing cultural variation (Brubaker, 2002; Barth, 1969; Jenkins, 1997). While their analytic vocabularies may vary, all these authors have in some way or another promoted the conception of ethnicity as the changing result of a social process.

To study the Romani perspective on citizenship requires full awareness of the fluidity of the category 'Roma'. The term 'Romani citizen' might be a confusing term, because it does not refer to an administratively registered identity but sometimes functions as such. Romani citizenship is primarily a matter of social organization and political expression, not of special legal status. Nevertheless, it is often portrayed and experienced as a widely accepted form of national or ethnic identity - and indeed both pro- and anti-Romani activists have at times argued in favour of some sort of administrative registration of that identity - and therefore it seems to have become as inescapable and enduring as any administratively fixed national category.

This chapter consists of two sections, divided along the lines of the concepts of experiences and acts of citizenship. By 'experiences', I refer to the diverse ways in which matters of legal status, i.e. the status attributed to individuals by states and the legal rights and obligations attached to this status (Bauböck, 2010, p. 847), impact on people who are associated with the label 'Roma'. This means that I reflect on issues related to 'citizenship as nationality', mostly in the context of various forms of migration across European state borders. As has been argued by Bauböck (2010, p. 848), such issues should be studied in a larger context of 'citizenship constellations': the legal status and rights of migrants are determined by the laws of their country of origin as well as by external citizenship, especially in the context of the European Union. By 'experiences' I also mean the way in which problems of social equality have been experienced from the Romani perspective. Seen as a 'social status that determines how economic and cultural capital are redistributed and recognized within society' (Isin and Turner, 2007, p. 14), citizenship has increasingly become a transnational attribute, i.e. that of values and rights that can be claimed across borders. As a result, social inequality, discrimination, poverty, and so forth are issues that should not merely be considered as domestic problems.

In the latter section of the chapter, the emphasis lies on acts of citizenship, by which I mean struggles for legal status or social equality in the name of a national or transnational form of citizenship. Here I briefly consider the active responses of those who are faced with some of the Romani experiences described earlier. How do activists mobilize Roma identity in order to achieve social or political change? These enactments are to a great extent defined within the political and institutional contexts in which they are articulated and are thus to be seen in interaction with political opportunity structures (McAdam et al., 1996) and internal or external framing processes (Snow and Benford, 1998; Benford and Snow, 2000).

The chapter is not exhaustive on these matters. It wants to make a modest attempt to start a dialogue between students of citizenship issues and those who are engaged in developing a more sophisticated empirical literature on Roma. Over the last few years the field of research on Roma-related issues in Europe, in sociology, political science, social history, linguistics, and social anthropology, has grown dramatically. Research has either intended to expand on previous knowledge on Roma in anthropology and linguistics or has tried to expand knowledge in particular subdomains - such as migration, ethnic mobilization, and Europeanization - by considering the main issues in these fields through the lens of the case of the Roma. In addition, Romani studies currently also comprises a vast body of policy-oriented empirical research aimed 
1 at informing governmental institutions and interest-driven studies by NGOs and international 2 organizations on issues such as discrimination, education, employment, health, and housing.

3 This chapter presents no new empirical data but relies on this growing number of studies to

4 substantiate a discussion in more integrated terms.

\section{Experiences of citizenship}

\section{Mobility and migration}

7 Citizenship issues have become tangible for Roma especially in the context of migration. Romani 8 asylum seekers, mostly from Central and Eastern Europe, have at various times been targeted for 9 collective expulsion (Cahn and Vermeersch, 2000). Concerns about an increase of asylum claimants have led individual EU member states to adopt ethnically framed migration control or highly restrictive immigration policies aimed at discouraging the entry of Roma (Cahn, 2003). Visa regulations for countries in Eastern and south-eastern Europe, for example, have had a particular impact on the experience of migrating Roma, independently of whether they intend to apply for asylum. As a result of negotiations on participation in the Schengen free visa regime, some countries in south-eastern Europe have restricted possibilities for Roma to travel to EU member states. Such restrictions are seldom officially sanctioned, but nevertheless tangible and consequential. For example, although the European Commission, through the visa liberalization dialogues with Macedonia, Serbia, Montenegro, Albania, and Bosnia and Herzegovina held between 2008 and 2010, set requirements regarding measures for the inclusion of marginalized Romani populations in the context of the EU's fundamental rights agenda, the net result of the negotiations was that in some cases Roma were prevented from migration. Pressure exerted from some EU countries - in one particular case, for example, from Belgium - pushed some sending countries into the adoption of measures aimed at lowering the number of ungrounded asylum claims. In some cases these measures involved ethnic profiling (Sardelić, 2013, p. 17). As is highlighted by Kacarska (2012, p. 19), in 'Macedonia local NGOs reported that Roma, who were kept from leaving Macedonia, had the letters 'AZ' [short version of asylum] stamped in their passport, indicating a ban on leaving the country.'

Apart from the issue of asylum and legal protection of migrated Roma from east to west, there is of course the parallel phenomenon of migration within certain Eastern European regions. Displacement and return, for example, are highly prevalent topics among Romani communities throughout the states of the former Yugoslavia, where displacement was in the first place a consequence of war and where post-war returns have functioned as a way to reverse ethnic cleansing. Of course, developments in this field affect other communities as well, but in the case of certain Romani communities, processes of displacement and return add further complexity to problems of exclusion and poverty (Kilibarda, 2011).

Intra-regional migration in Eastern Europe and the issue of migration across the borders of the EU is further compounded with intra-EU mobility. Also, this field can be seen from a Romani perspective. Since the expansion of the European Union, possibilities for East-West migration within the European Union have grown and a wide range of citizens from the eastern part of Europe have sought recourse to labour mobility. Of those who have moved within the EU in the context of the Free Movement Directive, only a small part are Roma. It is currently hard to make an informed estimate of the total number of Roma involved in this form of mobility, since there are no official data on the number of EU citizens exercising their right to free movement disaggregated by ethnic origin, and even the data by nationality (which can be collected from municipal registration data or work insurance registration figures) do not provide a full picture of 


\section{Peter Vermeersch}

the extent of Romani labour mobility from east to west, since a lot of that mobility is short-term and circulatory or takes place in unregistered form. Precisely because the numbers are unspecified, misleading information about Roma mobility can spread, and the phenomenon is likely to be exaggerated.

Such developments may lead to processes of racialization - when 'race' functions as 'the valorized language through which structured inequalities (measured in labour market position, differential access to scarce resources, legal status, and cultural stereotypes) are expressed, maintained, and reproduced.' (Fox, Morosanu, and Szilassy, 2012, p. 681). Such racialization has been signalled in the case of migration of Hungarians and Romanians. When UK tabloid newspapers write about these groups of labour migrants, as Fox, Morosanu, and Szilassy have shown, cultural difference operates as a criterion for exclusion and 'distinctive logics of colour and culture are combined to produce complementary effects: the dissemination and legitimation of public discourses on racialized difference'. Arguably, the Roma are even more prone to such racialization: no matter whether Romani migration is driven by factors that are similar to those that drive other migrations, the Roma are often framed as a special ethnocultural category of migrants because they are either seen as inherently deviant. These ideas may be inherited from romantic portrayals of wandering groups in popular culture or perhaps, as Lucassen, Willems and Cottaar (1998) have argued, they may be the result of categorization practices by authorities and academics in the eighteenth and nineteenth century who sought to unify all sorts of itinerant groups under the single label of 'Gypsy'. Whatever the sources of such imaginations are, they remain a powerful trope in public media discourseand therefore have profound effects on the situations in which these Romani migrants end up.

According to data gathered by the EU Fundamental Rights Agency (FRA) on the basis of a survey among Roma who move across EU borders to Finland, France, Italy, Spain, and the UK, many of those Roma face difficulties at border crossings and experience barriers when they seek registration, try to access national health systems, public housing, and other forms of social assistance (EU Agency for Fundamental Rights, 2009b). Such new barriers are not likely to persuade the Roma to place greater trust in their host societies. The situation of marginalization that they know from their home societies is thus likely to be reproduced in the host societies.

National politicians and mainstream media in the receiving EU member states have mostly regarded the east-west mobility of Roma within the EU as a threat to their own fragile labour markets and social security systems. In some cases, notably in Italy and in France, the government responded by introducing targeted expulsion and migration control strategies for these labour migrants. In the autumn of 2010, it was the French case that made international headlines (Nacu, 2012). Responding to riots after a police shooting in July 2010, President Nicolas Sarkozy called an emergency ministerial meeting at which it was decided to shut down a large number of irregular Romani dwellings and single out Bulgarian and Romanian Roma for an expulsion campaign that would send them back to their countries of origin, even if only temporarily. The 2010 crackdown was highly conspicuous because of its emphasis on security, its focus on foreigners, and its overtones of ethnic discrimination. But the policy was not new. France had been sending Romanian and Bulgarian citizens home even before 2010, as had Italy, Germany, Sweden, Denmark, Finland, and the United Kingdom. In a resolution adopted on 9 September 2010, the European Parliament condemned the French policy. In 2009, the French government had already deported about 9,000 Roma to Romania and Bulgaria. Also, other Western European countries (such as, Italy, Germany, Sweden, Denmark, Finland, and the United Kingdom) have for a number of years pursued targeted return campaigns. Mobility may not have yet become the Roma's preferred escape route from marginality, but expulsion has clearly become the preferred policy response to Romani migration. Several EU actors and institutions responded forcefully 
1 to the highly publicized campaigns. As van Baar (2011) documents, in a resolution adopted on 29 September 2010, the European Parliament condemned the French policy and urged the French 3 authorities to stop the expulsions immediately. The European Commission responded through 4 Viviane Reding, Commissioner for Justice, Fundamental Rights, and Citizenship, who was 5 particularly alarmed by the leaked memo of the French Interior Ministry that was distributed to 6 local civil servants and urged French police officials to focus their efforts on migrants of Romani 7 background. Reding first threatened to bring France before the European Court of Justice 8 for violating anti-discrimination laws but later, after the Commission received assurance from 9 France that it did not single out Roma, refrained from pursuing an infringement procedure. The main result of the intervention by Reding seems to have been the development of a number of new initiatives on the part of the European Commission that enable closer EU observation of the way in which member-states protect, or fail to protect, Romani communities. For example, in 2011 the European Commission adopted an EU Framework for National Roma Integration Strategies, which asks member states to design long-term plans with specific measures for the integration of Romani populations as well as robust monitoring mechanisms for the implementation of those plans.

\section{Exclusion and poverty}

Roma who have not migrated have still experienced citizenship-related issues in ways that differ from those of their non-Romani co-citizens. Some of those experiences relate to exclusion from citizenship documents as a result of the redefinition of national citizenship laws after the collapse of communism in Eastern Europe. For example, in 1993 the newly independent Czech Republic adopted a citizenship law that, for some years until it was amended, rendered approximately 10,000 to 25,000 Roma stateless (Linde, 2006). Exclusions as a result of war-related displacement have compounded the issue of new citizenship attainment even further in the exYugoslav countries (Sardelić, 2013).

Yet attainment of legal status is only part of the picture. Socio-economic inequalities, which relate to the domain of social citizenship, are often a greater concern. There are now various indicators that Romani communities across Europe live on average in more dire economic circumstances than their co-citizens, even if they have not migrated. This socio-economic marginalization affects various spheres of life and has produced problems of ill health, low-quality education, poverty, unemployment, and segregation. Particularly telling are statistics that have been compiled by the EU's Fundamental Rights Agency (FRA) and the World Bank. The 2009 summary report on the issue concludes: 'Many Roma and Travellers in the EU live in substandard conditions which fall far below even the minimum criterion of adequate housing' (EU Agency for Fundamental Rights, 2009a, p. 92). This is a matter of concern within the EU, where welfare systems mostly stay under the control of the individual member states (Schall, 2012) - and certainly outside the EU. Reports by international NGOs in areas outside the EU point to a severe lack of progress.

Many marginalized Roma live in urban slums or isolated ghettos in rural areas where a situation has arisen that perpetuates exclusion and poverty (Sobotka and Vermeersch, 2012, p. 813). Such forms of segregation have often led to different lifestyles for those populations that find themselves on the margins of society. In the context of regulatory practices that accompany modernization, such as the management of migration flows, urban planning, settlement policies, the controlling of borders, and the creation of a European citizenship, new forms of problematizing the Roma have emerged (Vermeersch, 2006; van Baar, 2012a). The inability of those who govern to create effective policies for equal and inclusive citizenship for the Roma has reinforced a climate of hatred against those who are marginalized. 


\section{Peter Vermeersch}

Unsurprisingly, those who argue against active policies for the inclusion of marginalized Romani populations often revert to cultural arguments and claim that the Roma cause their own predicament. Such views are often supported not only by extremist groups, but sometimes also by high-profile politicians, including MEPs (Vermeersch, 2012, p. 1207). In some cases, antiRoma speech is actively connected to a larger nationalist programme. In Hungary, for example, the extreme right Jobbik party 'promotes and perpetuates the cult of Trianon (the treaty ending World War I which 'dismembered' Hungary), licking past wounds to justify future territorial claims, whilst aggressively pushing a law-and-order agenda at home aimed at the supposed offenders of law and order, the Roma' (Fox and Vermeersch, 2010, p. 346).

\section{Acts of citizenship}

When activists speak in the name of the Roma in order to engage in a social struggle, they often do so by emphasizing a particular framing of the identity of their 'own' group. Social movement scholars (Della Porta and Diani, 1999; Edelman, 2001; McAdam et al., 1996; Guidry et al., 2000) have understood framing as a process through which movement actors promote an understanding of reality that increases chances for mobilizing support for their cause. Different authors have focused on different dimensions of the framing process - some have emphasized individual control, while others have highlighted contextual constraints. For example, Benford and Snow (2000) have argued that the process of framing does not take place in a vacuum. For them, framing is always negotiated and shaped by the multi-institutional arenas in which it takes place.

Citizenship struggles in the name of the Roma happen in various ways; they adapt to the circumstances and the particular policy domains in which they can be situated. In addition, activists need to direct their activism towards three levels (local, national, European), each of which implies certain framings of Romani identity. The Roma can be conceived of as a national minority, a migrant community, a social underclass, or a transnational European group. In several countries, different ways of conceiving the Roma and the problems facing them have coexisted and competed for dominance in public policy debates. Such different conceptions have also led to different movement strategies and policy outcomes.

On the local level, Romani communities may be organized in various types of identity groups. Their particular group-formation process happens in response to the broader dynamic of group-formation processes on that level. They do not always frame themselves as Romani activists, and they are not always framed as such by others. I will not discuss this very diverse world of local framing processes further, but rather focus below on two fields where such framing dynamics are more widely visible to a broader audience: the nation-state context and the field of transnational institutions.

\section{Nation-state perspectives}

Within the context of citizenship struggles in Central and Eastern Europe, Romani activists have frequently relied on a 'national minority frame'. This is particularly the case when these activists believe this represents a convenient way to find support from other national minorities and nonRomani supporters of minority rights. In Slovakia, for example, the political activities of the Hungarian minority have served as an example (Vermeersch, 2003). In various countries Roma are legally considered a national or ethnic minority and therefore receive certain entitlements. In some cases (Hungary, Croatia) minority self-government systems have been set up that allow elected minority representatives to participate in institutionalized forms of local or national consultative roles. Such minority councils have limited rights in the field of culture. 
Legal acts leading to minority citizenship for the Roma, such as the Hungarian Minority Act establishing the system of minority self-governments, reinforce the frame of the Roma as a national minority.

In a context where states recognize the Roma as a national or ethnic minority, cultural Romani organizations frequently function as privileged representatives of the larger group. Such organizations are central to the political endeavour of ensuring a collective voice for a minority, because they are identifiable, registered entities that can act as negotiating partners for policymakers. These activists may not all agree about who belongs and who does not belong to 'their' group. Some, for example, frame Romani identity as a matter of social class (Krizsán, 2012). Romani activists who have relied on that latter frame emphasize the detrimental social circumstances of Romani life, the need for social inclusion, and implicitly or explicitly argue that the protection of cultural aspects of Romani identity are less important or should be regarded as a matter of privacy.

If a system of minority recognition and consultation is in place that involves Romani representatives, the state can select or elect particular organizations to take part in policy discussions, thereby promoting certain frames of Romani identity and discouraging competing ones. In Hungary, for example, such a form of minority citizens' participation functions through elections. Hungary has granted thirteen officially recognized 'historical' minorities (twelve 'national minorities' with external kin states and the Roma as an 'ethnic minority') a form of cultural autonomy (Kovats 2000). Since the mid-1990s members of local self-governments in Hungary can be elected by the population of towns and villages where minorities are present in sufficient numbers, while the members of national minority self-governments (representing the minority at the country level) are elected by an electoral body that consists of the members of local minority self-governments.

While such systems of national minority representation ratify the Roma as minority citizens and thereby reinforce the framing of Romani identity as a national minority identity - and give the Roma a voice in local or national politics, they have not remained without criticism. In the case of Hungary, for example, the system has been criticized for taking away legitimacy from Romani organizations that do not seek policy influence through minority self-governments and for allowing the state to neglect to care about the overall inclusion of Roma in regular political institutions. It has also been criticized for being an inadequate instrument for remedying social exclusion (Koulish, 2002, 2003).

\section{Postnational perspectives}

The Roma have now become a prominent topic of human rights protection in Europe. The growth of a transnational advocacy network around the situation of the Roma has offered Romani activists unprecedented opportunities for political mobilization. Individual activists and domestic organizations can now find support from cross-border NGOs active in the field of human rights and thus build new alliances. But the success of international advocacy for the Roma has also created new problems with regard to voice and representation. Who can speak in the name of the Roma?

The current European attention given to the Roma by EU institutions has added another layer to ongoing developments regarding identity framing and problem formation. In 2005, 2006, and 2008 the European Parliament adopted new resolutions concerning the Roma. In addition, the European Council of December 2007 gave its full symbolic support to the European Commission for the organization of a series of 'European Roma Summits'. In April 2011 the European Commission adopted a Communication $(\operatorname{COM}(2011) 173)$ which called for an active dialogue with the Roma, both at national and EU level, and demanded clear policy commitments 


\section{Peter Vermeersch}

from the EU member states in the form of 'national Roma integration strategies'. As a result of this process there is now clearly a tendency among a growing group of policymakers and political elites to frame the Roma as a 'transnational European minority', that is a group that lives throughout Europe and constitutes a minority in every state but in contrast to other minorities has no clear national lobby or external homeland to defend its interests. Moreover, the idea has emerged that these European Roma suffer from similar problems of exclusion and marginalization wherever they are.

These new European policies and initiatives could be considered acts of postnational citizenship; they reinforce the framing of the Roma as a postnational group.

Romani organizations and activists have often responded positively to this frame. Overall, the European institutionalization of Romani policies and the actions on Romani issues by transnational human rights networks have reinforced the idea that Romani activism is best served by a practice of 'postnational citizenship' (Tambini, 2001) defined according to entitlements emerging from the transnational discourse and the practice of international human rights protection rather than from national citizenship.

There have, however, also been serious criticisms of this framing. Kovats for example, has warned of the danger inherent in such 'Europeanization', as it may create a division between the efforts to include the Roma and other national social policy efforts. He argues:

The superficial symbolism of Roma as a unique transnational people, the EU's 'largest ethnic minority' with no 'mother country', promotes the (nationalist) aspiration that there should be some form of special European governance for Roma. Yet, regardless of what distinct cultural characteristics Roma people may share to a greater or lesser extent (or not at all), Roma are also citizens with the same rights and subject to the same economic, legal and political systems, part of the same national societies and cultures as their non-Roma compatriots.

(Kovats, 2012, p. 3) 


\section{References}

7 Baar, Huub van (2011) “Europe's Romaphobia: problematization, securitization, nomadization', Environment and Planning D - Society \& Space, 29 (2): 203-12.

9 Baar, Huub van (2012a) 'Socio-economic mobility and neo-liberal governmentality in post-socialist Europe: activation and the dehumanisation of the Roma', Journal of Ethnic and Migration Studies, 38 (8): 1289-1304.

Baar, Huub van (2012b) The European Roma: minority representation, memory and the limits of transnational governmentality, Doctoral Diss. Amsterdam.

Barth, Fredrik (1969) Ethnic groups and boundaries: the social organization of culture difference, Boston, MA: Little, Brown and Co.

Bauböck, Rainer (2010) 'Studying citizenship constellations', Journal of Ethnic and Migration Studies, 36 (5): 847-59.

Benford, Robert D. and Snow, David A. (2000) 'Framing processes and social movements: an overview and assessment', Annual Review of Sociology, 26: 611-39.

Brubaker, Rogers (2002) 'Ethnicity without groups', European Journal of Sociology, 43 (2): 163-89.

Cahn, Claude (2003) 'Racial preference, racial exclusion: administrative efforts to enforce the separation of Roma and Non-Roma in Europe through migration controls', European Journal of Migration and Law, 5 (4): 479-90.

Cahn, Claude and Vermeersch, Peter (2000) 'The group expulsion of Slovak Roma by the Belgian government: a case study of the treatment of Romani refugees in Western countries', Cambridge Review of International Affairs, 13 (2): 71-82.

Della Porta, Donatella and Diani, Mario (1999) Social movements: an introduction, Oxford: Blackwell Publishers.

Edelman, Marc (2001) 'Social movements: changing paradigms and forms of politics', Annual Review of Anthropology, 30: 285-317.

EU Agency for Fundamental Rights (2009a) Housing conditions of Roma and Travellers in the European Union: comparative report October 2009, Vienna: FRA.

EU Agency for Fundamental Rights (2009b) The situation of Roma EU citizens moving to and settling in other EU member states, Luxembourg: Office for Official Publications of the European Communities.

Fox, Jon E. and Vermeersch, Peter (2010) 'Backdoor nationalism', European Journal of Sociology, 51 (2): 325-57.

Fox, Jon E., Morosanu, L., and Szilassy, E. (2012) 'The racialization of the new European migration to the UK', Sociology, 46 (4): 680-95.

Guidry, John A., Kennedy, Michael D., and Zald, Mayer N. (2000) Globalizations and social movements. culture, power, and the transnational public sphere, Ann Arbor, MI: The University of Michigan Press.

Isin, Engin F. and Turner, Bryan S. (2007) 'Investigating citizenship: an agenda for citizenship studies', Citizenship Studies, 11 (1): 5-17.

Jenkins, Richard (1997) Rethinking ethnicity. arguments and explorations, London, Thousand Oaks, CA, and New Dehli: Sage.

Kacarska, Simonida (2012) 'Europeanisation through mobility: visa liberalisation and citizenship regimes in the Western Balkans'. Available online at www.law.ed.ac.uk/file_download/series/374_europeanisationthroughmobilityvisaliberalisationandcitizenshipregimesinthewester.pdf (accessed 4 July 2103).

Kilibarda, Konstantin (2011) 'Clearing space: an anatomy of urban renewal, social cleansing and everyday life in a Belgrade mahala', Cambridge Review of International Affairs, 24 (4): 37-41.

Koulish, Robert E. (2002) 'Opportunity lost? The social (dis)integration of Roma minority rights in posttransition Hungary', Nationalism and Ethnic Politics, 8 (1): 81-104.

Koulish, Robert E. (2003) 'Attitudes towards Roma minority rights in Hungary: a case of ethnic doxa, and the contested legitimization of Roma inferiority', Nationalities Papers, 31 (3): 327-45.

Kovats, Martin (2000) 'The political significance of the first National Gypsy Minority Self-government in Hungary', Contemporary Politics, 6 (3): 247-62.

Kovats, Martin (2001) 'The emergence of European Roma policy', in W. Guy (ed.), Between past and future: the Roma of Central and Eastern Europe, Hatfield: University of Hertfordshire Press: 93-116. 


\section{Peter Vermeersch}

Kovats, Martin (2012) 'The EU's Roma role', Open Democracy, (11 May), 1-4. Available online at www. opendemocracy.net (accessed 4 July 2103).

Krizsán, Andrea (2012) 'Group self-determination, individual rights, or social inclusion? Competing frames for ethnic counting in Hungary’, Ethnic and Racial Studies, 35 (8): 1392-1408.

Liégeois, Jean-Pierre and Gheorghe, Nicolae (1995) Roma/Gypsies: a European minority, London: Minority Rights Group International.

Linde, Robyn (2006) 'Statelessness and Roma communities in the Czech Republic: competing theories of state compliance', International Journal on Minority and Group Rights, 13 (4): 341-65.

Lucassen, Leo, Willems, Wim, and Cottaar, Annemarie (1998) Gypsies and other itinerant groups: a socio-historical approach, London: Macmillan.

McAdam, Doug, McCarthy, John D., and Zald, Mayer N. (1996) Comparative Perspectives on social movements: political opportunities, mobilizing structures, and cultural framings, Cambridge: Cambridge University Press.

Nacu, Alexandra (2012) 'From silent marginality to spotlight scapegoating? A brief case study of France's policy towards the Roma', Journal of Ethnic and Migration Studies, 38 (8): 1323-8.

Petrova, Dimitrina (2003) 'The Roma: between a myth and the future', Social Research, 70 (1): 111-61.

Sardeli , Julija (2013) 'Romani minorities in the context of post-Yugoslav citizenship regimes'. Presented at 18th ASN World Convention, Columbia University, New York, 2013.

Schall, Carly Elizabeth (2012) 'Is the problem of European citizenship a problem of social citizenship? Social policy, federalism, and democracy in the EU and United States', Sociological Inquiry, 82 (1): 123-44.

Simhandl, Katrin (2006) "Western Gypsies and Travellers"-"Eastern Roma": the creation of political objects by the institutions of the European Union', Nations and Nationalism, 12 (1): 97-115.

Snow, David A. and Benford, Robert D. (1998) 'Ideology, frame resonance, and participant mobilization', International Sociological Movement Research, 1: 197-218.

Sobotka, Eva and Vermeersch, Peter (2012) 'Governing human rights and Roma inclusion: can the EU be a catalyst for local social change?', Human Rights Quarterly, 34 (3): 800-22.

Stewart, Michael (ed.) (2012) The Gypsy 'menace', London: Hurst \& Company.

Tambini, Damian (2001) 'Post-national citizenship', Ethnic and Racial Studies, 24 (2): 195-217.

Vermeersch, Peter (2003) 'Ethnic minority identity and movement politics: the case of the Roma in the Czech Republic and Slovakia', Ethnic and Racial Studies, 26 (5): 879-901.

Vermeersch, Peter (2005) 'Marginality, advocacy, and the ambiguities of multiculturalism: notes on Romani activism in Central Europe', Identities: Global Studies in Culture and Power, 12 (4): 451-78.

Vermeersch, Peter (2006) The Romani movement: minority politics and ethnic mobilization in contemporary Central Europe, Oxford, New York: Berghahn Books.

Vermeersch, Peter (2012) 'Reframing the Roma: EU initiatives and the politics of reinterpretation', Journal of Ethnic and Migration Studies, 38 (8): 1195-1212.

Vermeersch, Peter (2013) 'The European Union and the Roma: an analysis of recent institutional and policy developments', European Yearbook of Minority Issues, 10: forthcoming.

Woodcock, Shannon (2007) 'Romania and EUrope: Roma, Rroma and Țigani as sites for the contestation of ethno-national identities', Patterns of Prejudice, 41 (5): 493-515. 